\title{
Correction to: The $J$-area integral applied in peridynamics
}

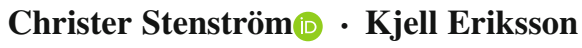

Accepted: 2 February 2021 / Published online: 12 April 2021

(C) Springer Nature B.V. 2021

\section{Correction to: Int J Fract \\ https://doi.org/10.1007/s10704-020-00505-8}

The original online version of this article was revised because of errors made in the production process regarding the lay out.

Publisher's Note Springer Nature remains neutral with regard to jurisdictional claims in published maps and institutional affiliations.

The online version of the original article can be found under https://doi.org/10.1007/s10704-020-00505-8.

C. Stenström $(\varangle) \cdot$ K. Eriksson

Mechanics of Solid Materials, Luleå University of

Technology, Luleå, Sweden

e-mail: christer.stenstrom@1tu.se

K. Eriksson

e-mail: kjell.eriksson@1tu.se

C. Stenström

Luossavaara-Kiirunavaara Aktiebolag (LKAB), Luleå, Sweden 